\title{
Total antioxidant activity and trace elements in human milk: the first 4 months of breast-feeding
}

\author{
Carla Matos · Carla Moutinho • Victor Balcão • \\ Cristina Almeida $\cdot$ Marta Ribeiro $\cdot$ \\ Agostinho Franklim Marques • António Guerra
}

Received: 21 May 2009 / Revised: 28 July 2009 / Accepted: 15 September 2009 / Published online: 10 October 2009

(C) Springer-Verlag 2009

\begin{abstract}
The content of many nutrients in breast milk are dependent on the nutritional status of the lactating woman. This is particularly true for fat and water-soluble vitamins, some of which have antioxidant properties. The aim of the study entertained herein was to evaluate the changes in total antioxidant status of human milk during the first 4 months of lactation, and to correlate such changes with the contents in specific antioxidant oligoelements $(\mathrm{Cu}, \mathrm{Zn}, \mathrm{Mn}$ and $\mathrm{Se})$. Milk samples were collected from (31) lactating women recruited at the Service of Obstetrics of the Hospital de São João in Porto, after 1, 4, 8, 12 and 16 weeks after birth. The total antioxidant status (TAS) of human milk was measured by the Randox ${ }^{\circledR}$ commercial kit and trace metals by ICPMS (inductively coupled plasma-mass spectrometry). The results found for TAS and oligoelements under study show a decrease in the concentration of these parameters from
\end{abstract}

C. Matos $(\bowtie) \cdot$ C. Moutinho $\cdot$ V. Balcão $\cdot$ C. Almeida Grupo de Investigação em Bioengenharia e Química Biofarmacêutica, Faculdade de Ciências da Saúde, Universidade Fernando Pessoa, Praça 9 de Abril no 349 , 4249-004 Porto, Portugal

e-mail: cmatos@ufp.edu.pt

C. Moutinho $\cdot$ V. Balcão

Instituto para a Biotecnologia e a Bioengenharia (IBB), Centro de Engenharia Biológica, Universidade do Minho,

Campus de Gualtar, 4710-057 Braga, Portugal

M. Ribeiro · A. Guerra

Serviço de Neonatologia, Departamento de Pediatria, Hospital de São João, Alameda Prof Hernâni Monteiro, 4202-451 Porto, Portugal

\section{A. F. Marques}

Departamento de Análises Clínicas e Bioquímica, Faculdade de Farmácia, Universidade do Porto, Rua Aníbal Cunha, 164, 4250-542 Porto, Portugal
7 days to 4 months of breast-feeding and significant correlations $(p<0.05)$ were found between TAS and $\mathrm{Cu}, \mathrm{Zn}$ and $\mathrm{Se}$ (not $\mathrm{Mn}$ ). The decreases of $\mathrm{Cu}, \mathrm{Zn}$ and Se were also correlated, but not proportional between them, suggesting diverse excretion mechanisms for all. Between primipara and multipara women, a significant difference was found only for $\mathrm{Cu}$ and $\mathrm{Zn}$ concentrations at 7 days of lactation, but not for the other metals or TAS. With respect to the mother's age, no correlation was found, either for trace metal concentrations or TAS.

Keywords Micronutrients · Breast-feeding · Trace elements · Human milk · Oxidative stress · Total antioxidant status

\section{Introduction}

Human milk (HM) is the first food human babies encounter and serves as the sole source of all nutrients required for the biological functions, growth and development during the early stages of life $[1,2]$, being the most perfect and natural food for newborn babies. Breast milk (BM) from healthy women contains all the necessary nutrients for newborn infants and also a variety of growth and immune factors, together with many other components that protects them [13]. Amongst these, BM contains a plethora of antioxidant molecules that can help prevent oxidative stress situations, offering a vital antioxidant protection to the newborn at the early stages of life [4]. The protection afforded by BM is due to a complex system of host defense factors that are distinct from those of other mammalian milks [5, 6]. The process of childbirth is accompanied by an increase in oxidative stress, as birth is, in itself, a hyperoxic challenge, and so antioxidants are indeed a vital component in the diet of the 
newborns. The complete list of active antioxidant molecules in $\mathrm{HM}$ is not known, but vitamins $\mathrm{C}, \mathrm{E}$, and $\mathrm{A}, \alpha$-tocopherol, lactoferrin, lactoperoxidase, cysteine, ascorbate and carotenoids have been found [1-3,5], together with antioxidant enzymes such as glutathione peroxidase (GPx), catalase and superoxide dismutase (SOD) $[1,7,8]$. Oxidative stress tends to occur during the neonatal period because the younger the gestational age, the lower the total antioxidant status (TAS), which results in an increase in free radicals (FR) and reactive oxygen species (ROS) [4, 5, 8-10]. In adults, there is increasing evidence that these radicals are related to risk for cancer, coronary artery disease, cataracts, and to the function of the immune system [11-13], and in premature or malnourished infants may be involved in diseases of the eyes, lungs and brain [1, 4, 14-18]. Antioxidants are benefic because they neutralize ROS and FR [1], thereby preventing these oxidizing agents from reacting with otherwise stable constituents in the body to cause cellular damage. Such antioxidant system involves not only a variety of biomolecules such as enzymes, but also some trace elements (e.g. $\mathrm{Cu}, \mathrm{Zn}$, $\mathrm{Mn}$ and Se). Therefore, the maternal supply of antioxidant vitamins during lactation may provide a defense mechanism to reduce oxidative stress [19]. The TAS is a parameter characterizing the sum of the activities of all antioxidants present in human BM [20, 21].

The concentration of many trace elements changes as lactation progresses (the more significant variations occur in the passage from transition milk to mature milk) but milk composition also varies between women $[22,23]$. There is extensive literature on the longitudinal variations of trace elements concentration in mature HM [24-26]. Some trace elements (e.g. $\mathrm{Cu}, \mathrm{Zn}, \mathrm{Mn}$ and $\mathrm{Se}$ ), which can act as redox catalysts, form part of the active site or are cofactors of antioxidant enzymes [7, 22, 23, 27, 28], can act as antioxidants. $\mathrm{Cu}$ is a transition metal, playing a role as cofactor in the transcription of $\mathrm{Cu} / \mathrm{Zn}$ superoxide-dismutase $(\mathrm{Cu} / \mathrm{Zn}$ $\mathrm{SOD}$ ) and, therefore, a diet poor in $\mathrm{Cu}$ significantly reduces the expression of $\mathrm{Cu} / \mathrm{Zn}-\mathrm{SOD}$ in human tissues [7, 29]. $\mathrm{Cu}$ itself can act as a mediator for oxidative stress, catalyzing the decomposition of hydroperoxide to form FR [7].

$\mathrm{Zn}$ has not such an evident effect on the expression of $\mathrm{Cu} /$ $\mathrm{Zn}$-SOD, but apparently plays an indirect role as antioxidant $[7,30,31]$, and there are several essential enzymes regulated or activated by $\mathrm{Zn}[22,32,33]$. $\mathrm{Zn}$ is an essential trace element, especially for newborns. Despite that BM contains lower concentrations of $\mathrm{Zn}$ compared to industrial formulæ, breast-fed newborns often display a more suitable and balanced $\mathrm{Zn}$ status compared to non-breast-fed ones [22, 33-36].

$\mathrm{Mn}$ is a trace element known to activate many enzymes involved in metabolic processes, being the key element at the active site in many Mn-enzymes. Mn is one of the key elements for enzymes in energy production and increases the level of antioxidant protection, especially in mitochon- drial Mn-SOD [33]. Mn is involved in utilization of vitamins $\mathrm{B}_{1}$ and $\mathrm{E}$, and it is required for normal bone growth or for avoiding clotting defects [33].

Se is an essential trace element for humans and sufficient Se supply can protect against several heart diseases and provides a certain level of protection against cancer [33, 36]. The detoxifying effects of Se are vastly proven and described widely in the literature [37-39]. Se is an integral part of the GPx enzyme [39] that protects against oxidative damage, and as a component of the active site of this enzyme selenium plays a role in antioxidant reactions [7, 37, 39]. Se-deficiency is most critical for the brain and growth of infants $[37,40]$. Newborns initially show serum Se levels of around $80 \mu \mathrm{g} / \mathrm{L}$ [41] or slightly decreased (50$60 \mu \mathrm{g} / \mathrm{L}$ ) ones [42]. Furthermore, the total Se concentration in $\mathrm{BM}$ decreases from colostrum $(20-80 \mu \mathrm{g} / \mathrm{L})$ [43] to mature milk to a range of $5-18 \mu \mathrm{g} / \mathrm{L}$ [43].

It has been reported that early breast-feeding is important in a number of respects, including the fact that the earlier breast-feeding begins, the lower mortality is [44]. The aim of the study entertained herein was to prospectively follow the changes in TAS of HM during the first 4 months of lactation, and to correlate such changes with the contents in specific antioxidant oligoelements $(\mathrm{Cu}, \mathrm{Zn}, \mathrm{Mn}$ and $\mathrm{Se})$, in order to assess the role of such elements is the TAS throughout the lactation.

\section{Materials and methods}

\section{Subjects}

Recruiting of lactating women took place at the Service of Obstetrics of Hospital de São João in Porto, Portugal. Regarding the mothers, the criteria for inclusion in the study were (i) to have a watched over gestation, (ii) to have decided to breast-feed the baby and (iii) to live in Porto, while the criteria for exclusion were (i) to have a pathology preventing breast-feeding (tumor, HIV carrier, hepatitis B or $\mathrm{C}$ carrier) and (ii) to be under pharmacological therapy preventing breast-feeding. Regarding the babies, the criteria for inclusion in the study were (i) to have an adequate weight to the gestational age, (ii) to be a term newborn (gestation equal or higher than 37 weeks), and (iii) to be fed exclusively or at least partially with mother milk until 4 months of age, while the criteria for exclusion were (i) being a premature newborn, (ii) having pathologies or intercurrences preventing breast-feeding or that interfere with normal growth (neurological and metabolic diseases, polymalformative syndromes, congenit cardiopathies, or others preventing breast-feeding), and (iii) being term newborns but possessing inadequate weight (both low or higher) for the gestational age. 
One hundred and two lactating women gave their consent to participate in the study after explanation of the procedures, but only 31 completed the study. The age of the women that entered the study ranged between 21 and 39 years old, with an average (and standard deviation) of $30.9 \pm 3.9$ years old. All infants were fully breast-fed on demand for 4 months. All 31 mothers maintained their own breast-feeding patterns throughout the entire time frame of study. All procedures were duly approved by the Hospital Ethical Committee.

\section{Milk samples}

Breast milk samples were collected by either breast pump or hand expression, before and after each feed, from each breast, over a $24 \mathrm{~h}$ period. Samples were collected after 1 , 4, 8, 12 and 16 weeks of giving birth. On a particular day, milk samples $(5 \mathrm{~mL}$ before and $5 \mathrm{~mL}$ after each feeding, from each breast, throughout the day; approximately $100 \mathrm{~mL}$ were collected each day) were collected to sterile and trace metals free plastic containers several times during that day, kept refrigerated at $4{ }^{\circ} \mathrm{C}$ and pooled together to produce a milk sample for analysis. Therefore, each HM sample produced was in fact representative of the average milk composition of that particular day. Samples were homogenized and were initially stored in a household freezer for a maximum of $24 \mathrm{~h}$ and then transported on ice to the laboratory, where they were stored at $-80^{\circ} \mathrm{C}$ until analysis. Milk samples were thawed and vortexed until homogenization prior to analysis.

Total antioxidant status analysis

The TAS was determined in the present research effort using the Randox ${ }^{\circledR}$ assay, which is based on the method of Miller and coworkers [21], by measuring the collective activity of all antioxidants in the BM sample $(5 \mu \mathrm{L})$ by the 2,2' -azinobis(3-ethylbenzothiazoline-6-sulfonic acid) radical cation $\left(\mathrm{ABTS}^{+}\right)$assay ( Randox $^{\circledR}$ commercial kit). This method is based on the ability of antioxidant molecules to quench the long-lived 2,2'-azinobis(3-ethylbenzothiazoline-6-sulfonic acid) radical cation $\left(\mathrm{ABTS}^{-+}\right)$a blue-green chromophore with characteristic absorption at $600 \mathrm{~nm}$, in comparison to that of Trolox, a water-soluble vitamin $\mathrm{E}$ analogue, used as a standard for calibration. Results are expressed in $\mathrm{mmol} / \mathrm{L}$ of Trolox equivalents.

Determination of trace metals by ICP-MS (inductively coupled plasma-mass spectrometry)

In the preparation of all solutions, ultrapure water (resistivity higher than $18 \mathrm{M} \Omega \mathrm{cm}$ ) obtained through a Milli-QTM system (Millipore; Billerica, MA, USA) was used. All reagents used were of analytical grade or better, except for nitric acid, which was of Suprapur ${ }^{\circledR}$ grade (Merck, Darmstadt, Germany). Special care was taken to avoid contamination during sample preparation. Adequately acid-washed plastic materials were used at all times.

Metal determination was performed by using a VG Elemental (Winsford, UK), PlasmaQuad 3 ICP-MS, equipped with a Meinhard ${ }^{\circledR}$ type A pneumatic concentric nebulizer, a quartz water cooled impact-bead spray chamber, a standard quartz tube torch and nickel sample and skimmer cones. Both the spray chamber and sampling interface were cooled down to $10{ }^{\circ} \mathrm{C}$ by circulating water. All samples, after adequate dilution, were analyzed twice (two replicates). The following elemental isotopes $(\mathrm{m} / \mathrm{z}$ ratios) were monitored: as analytical masses ${ }^{55} \mathrm{Mn},{ }^{65} \mathrm{Cu},{ }^{66} \mathrm{Zn},{ }^{82} \mathrm{Se}$ and as internal standards ${ }^{45} \mathrm{Sc},{ }^{89} \mathrm{Y},{ }^{115} \mathrm{In},{ }^{159} \mathrm{~Tb}$ and ${ }^{209} \mathrm{Bi} .{ }^{83} \mathrm{Kr}$ and ${ }^{77} \mathrm{ArCl}$ were also monitored to correct instrumental isobaric interferences. The instrument was tuned daily for maximum signal sensitivity and stability using ${ }^{115}$ In as the target isotope.

Samples for $\mathrm{Cu}$ and $\mathrm{Zn}$ determination were diluted (1:50) with a $2 \%(\mathrm{v} / \mathrm{v}) \mathrm{HNO}_{3}$ and $0.01 \%$ (v/v) Triton X-100 solution prior to analysis. Samples for Mn and Se were analyzed after microwave oven (Milestone, model MLS 1200 mega) digestion. For this procedure, $2 \mathrm{~g}$ of milk (accurately weighed) were placed in Teflon vessels, added with $1 \mathrm{~mL}$ of $65 \% \mathrm{HNO}_{3}$ (Suprapur, Merck) and $1 \mathrm{~mL}$ of $30 \% \mathrm{H}_{2} \mathrm{O}_{2}$ (pro analysis, Merck, Darmstadt, Germany) and digested according to the following programme $(\mathrm{min} / \mathrm{W})$ : step $1(1 /$ 250); step 2 (2/0); step 3 (5/250); step 4 (5/400); step 5 (5/ 600 ). After cooling (ca. $30 \mathrm{~min}$ ), the digestion solutions were transferred into a $10 \mathrm{~mL}$ volumetric flask and diluted with ultrapure water (Milli-Q, Millipore).

ICP-MS calibration solutions were prepared by dilution of a commercial multi-element aqueous solution (AccuTrace $^{\mathrm{TM}}$ Reference Standard, Calibration Standard 1R, AccuStandard Inc., CT, EUA) $10 \mu \mathrm{g} / \mathrm{mL}$ (in $2 \% \mathrm{HNO}_{3}$ ), except Se $(50 \mu \mathrm{g} / \mathrm{mL})$, using $2 \%$ (v/v) $\mathrm{HNO}_{3}$ and $0.01 \%$ (v/ v) Triton $\mathrm{X}-100$ solution. Internal standards were added to the diluting solutions via dilution of a commercial aqueous solution (AccuTrace ${ }^{\mathrm{TM}}$ Reference Standard, Internal Standard \#1, AccuStandard Inc., CT, EUA), containing 5 components $(\mathrm{Bi}, \mathrm{In}, \mathrm{Sc}, \mathrm{Tb}, \mathrm{Y})$ in a concentration of $100 \mu \mathrm{g} / \mathrm{mL}$ (in $2 \% \mathrm{HNO}_{3}$ ) in order to attain a final concentration of $50 \mu \mathrm{g} / \mathrm{L}$. Because the levels of $\mathrm{Zn}$ and $\mathrm{Cu}$ were much higher than those of the other elements analyzed, their concentrations in the calibration solutions (prepared as described above) was increased via addition of a commercial standard stock solution of each element $(\mathrm{Cu}$ Standard Solution 1,000 mg/L, BDH SpectrosoL ${ }^{\circledR}$, Poole, England; Zn Standard Solution 1,000 mg/L, Merck, Darmstadt, Germany). 
Statistical analyses

A thorough statistical analysis was performed to the experimental data gathered, using the software package Statistical Package for Social Sciences (SPSS) version 15.0 for Windows (SPSS Inc., Chicago, IL, USA). Normal distribution was assessed via the Kolmogorov-Smirnov test. For each group, means within time were compared by using a paired samples $t$ test. Correlations between means were assessed by Pearson's correlation analyses of ranks. Statistical significance was set at $p<0.05$.

\section{Results}

All variables under scrutiny were found to follow a normal distribution $(p<0.05)$, following application of the Kolmogorov - Smirnov test. The results obtained, together with descriptive statistics for TAS, Cu, $\mathrm{Zn}, \mathrm{Se}$ and $\mathrm{Mn}$ are summarized in Table 1.

The results obtained clearly show a decrease tendency for all the parameters under study (TAS, $\mathrm{Cu}, \mathrm{Zn}$, Se and $\mathrm{Mn}$ ), as can be observed in Figs. 1 and $2 \mathrm{a}-\mathrm{d}$.
In the case of TAS (see Fig. 1), a significant difference $(p<0.001)$ is observed between the results obtained for BM after 7 days and 4 weeks of lactation, but not for the subsequent collection times. For $\mathrm{Cu}$ and Se (see Figs. 2a, b), significant difference ( $p<0.001)$ was found until the 8th week post-partum, while for $\mathrm{Zn}$ (see Fig. 2c) a significant difference $(p<0.001)$ is observed until the 12 th week of lactation. In the case of Mn (see Fig. 2d) there appears to be a drop in the concentration of this metal at the 8th week, and again at 16th week of lactation (significant differences ( $p<0.001$ ) found between the 4 th and 8th, and the 12th and 16 weeks).

Results were analyzed as a function of age and parity of women. No statistically significant differences were observed between mothers older and younger than 30 years. With respect to parity, primipara women show statistically different (increased) $(p<0.01)$ amounts of $\mathrm{Cu}$ and $\mathrm{Zn}$ in milk at 7 days of lactation, but not in subsequent lactation periods. No differences were found for Se at any lactation time, but for Mn there appears to be a statistically meaningful $(p<0.01)$ increase in primipara women throughout the entire lactation timeframe under study.
Table 1 Statistical data pertaining to TAS (data in $\mathrm{mmol} / \mathrm{L}$ ) and oligoelements (data in $\mu \mathrm{g} / \mathrm{kg}$ ) in (human) breast milk, as a function of lactation time
*Indicates significant differences from previous (4-8 weeks, for example) values $(p<0.01)$

\begin{tabular}{|c|c|c|c|c|c|c|}
\hline & Time & Mean & Std. deviation & Median & Min. & Max. \\
\hline \multirow[t]{5}{*}{ TAS } & 7 days & 0.497 & 0.094 & 0.480 & 0.360 & 0.820 \\
\hline & 4 weeks & $0.399 *$ & 0.076 & 0.420 & 0.240 & 0.590 \\
\hline & 8 weeks & 0.423 & 0.094 & 0.405 & 0.260 & 0.660 \\
\hline & 12 weeks & 0.401 & 0.089 & 0.375 & 0.250 & 0.590 \\
\hline & 16 weeks & 0.375 & 0.092 & 0.370 & 0.170 & 0.670 \\
\hline \multirow[t]{5}{*}{$\mathrm{Cu}$} & 7 days & 529.0 & 149.6 & 555.6 & 236.7 & 812.6 \\
\hline & 4 weeks & $379.6^{*}$ & 93.7 & 393.2 & 214.6 & 533.0 \\
\hline & 8 weeks & $292.4^{*}$ & 77.0 & 294.8 & 139.0 & 442.1 \\
\hline & 12 weeks & 259.5 & 94.6 & 248.8 & 89.2 & 503.6 \\
\hline & 16 weeks & 240.7 & 98.0 & 253.2 & 39.9 & 402.4 \\
\hline \multirow[t]{5}{*}{$\mathrm{Zn}$} & 7 days & 4010.6 & 1177.7 & 3922.0 & 2073.0 & 6781.0 \\
\hline & 4 weeks & $2160.6^{*}$ & 589.4 & 2041.0 & 1218.0 & 3655.0 \\
\hline & 8 weeks & $1491.4^{*}$ & 619.5 & 1423.0 & 322.1 & 2956.0 \\
\hline & 12 weeks & $1084.2 *$ & 537.2 & 1065.0 & 205.7 & 2195.0 \\
\hline & 16 weeks & 1014.1 & 461.5 & 974.6 & 155.3 & 2216.0 \\
\hline \multirow[t]{5}{*}{$\mathrm{Mn}$} & 7 days & 3.73 & 2.64 & 2.54 & 0.47 & 9.36 \\
\hline & 4 weeks & 3.65 & 1.99 & 3.21 & 0.77 & 9.46 \\
\hline & 8 weeks & $2.29 *$ & 1.13 & 2.55 & 0.14 & 4.39 \\
\hline & 12 weeks & 2.86 & 1.67 & 2.62 & 0.15 & 5.76 \\
\hline & 16 weeks & $2.44 *$ & 1.49 & 2.47 & 0.00 & 5.91 \\
\hline \multirow[t]{5}{*}{$\mathrm{Se}$} & 7 days & 30.69 & 9.21 & 30.26 & 15.07 & 54.33 \\
\hline & 4 weeks & $25.47 *$ & 7.10 & 23.36 & 12.34 & 39.57 \\
\hline & 8 weeks & $19.95^{*}$ & 6.76 & 19.92 & 3.36 & 31.04 \\
\hline & 12 weeks & 20.16 & 5.38 & 18.49 & 12.47 & 32.18 \\
\hline & 16 weeks & 19.49 & 3.58 & 19.66 & 14.46 & 26.37 \\
\hline
\end{tabular}


Fig. 1 Evolution of the total antioxidant status $(\mathrm{mmol} / \mathrm{L})$ of breast milk as a function of lactation week

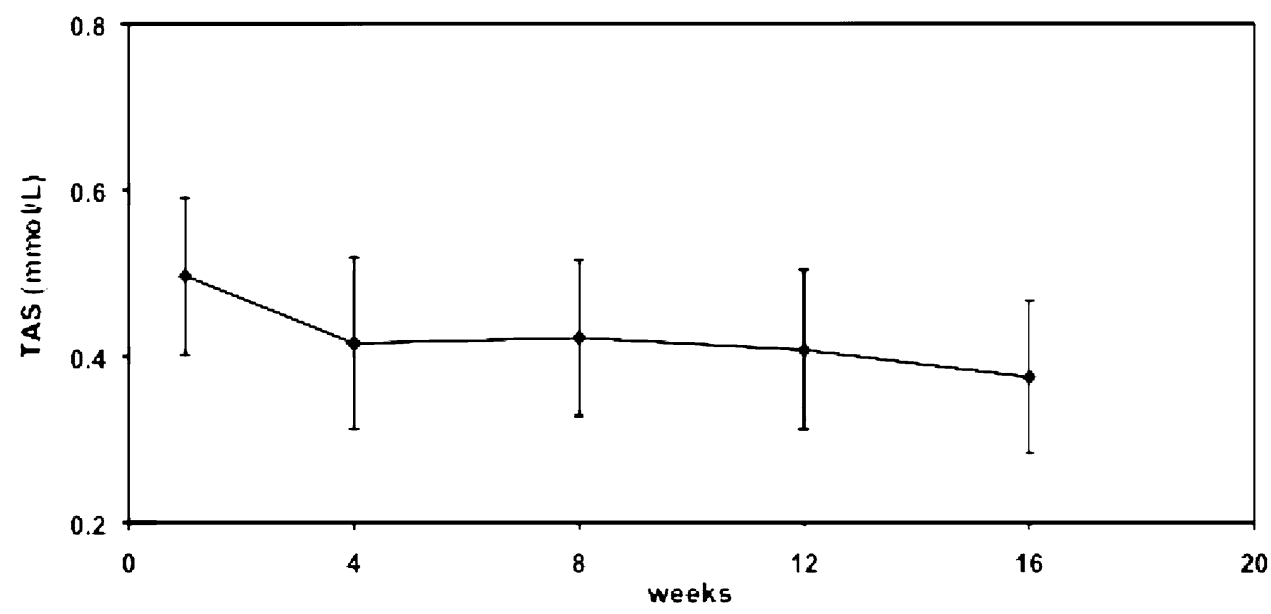

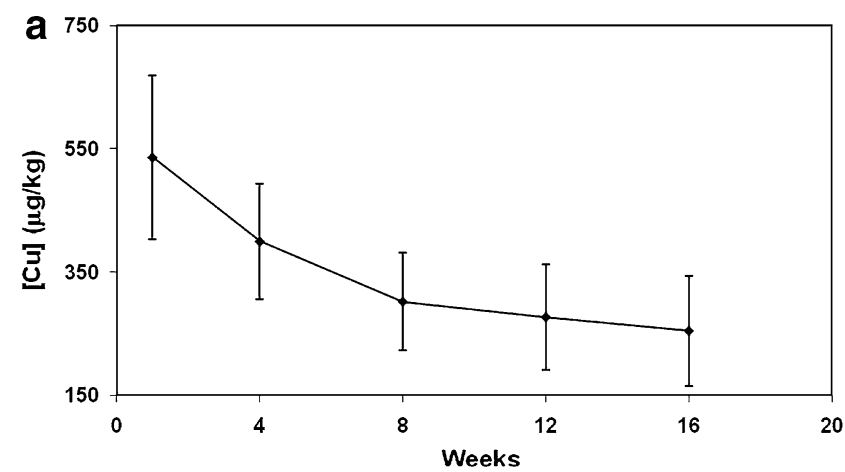
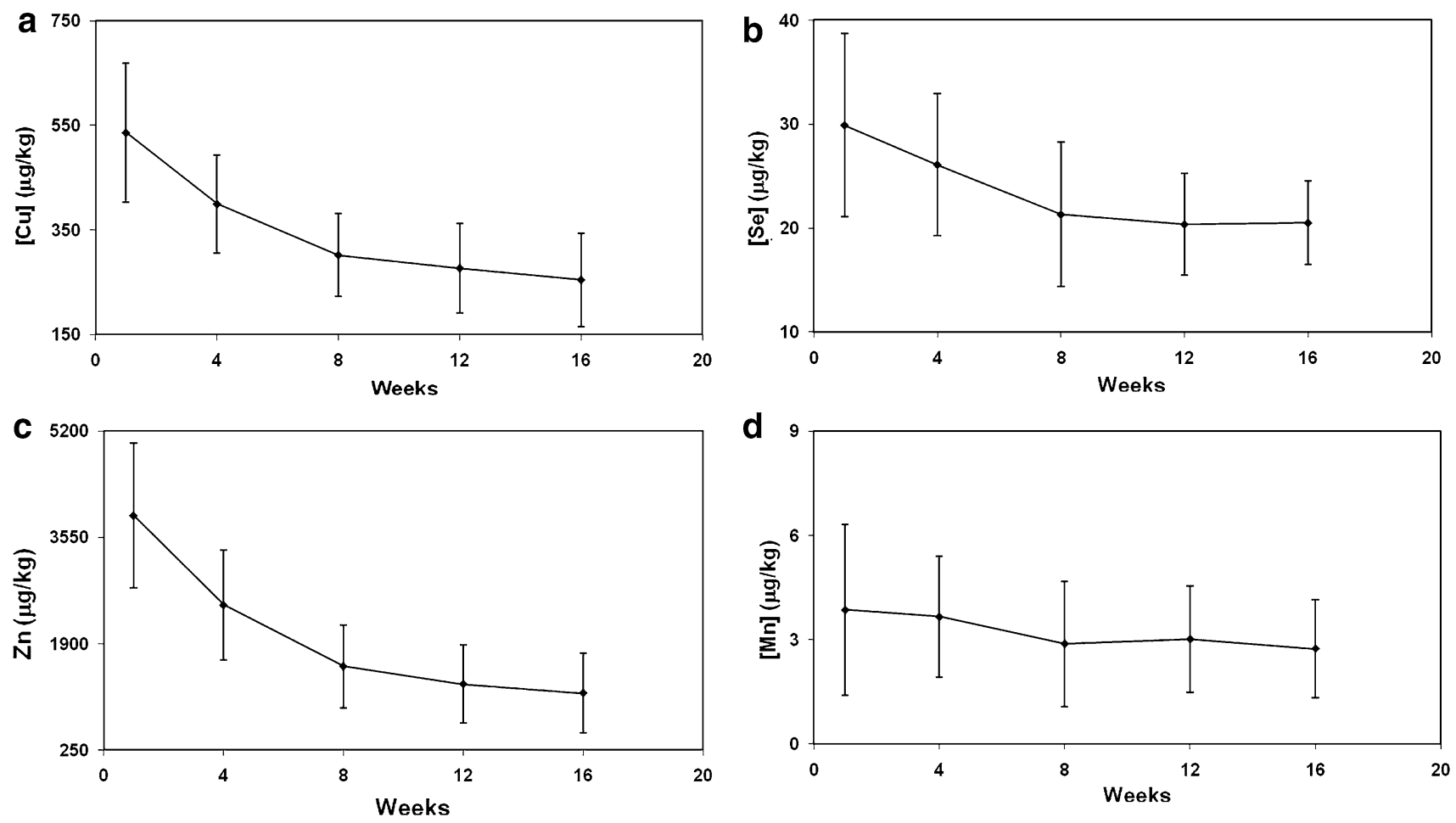

Fig. 2 Evolution of the concentration $(\mu \mathrm{g} / \mathrm{kg})$ of oligoelements in breast milk as a function of lactation week: a Copper; b Selenium; c Zinc; and d Manganese

Correlations between TAS and mean metal concentrations along the lactation period studied, as well as amongst metals were evaluated. Strong correlations were observed between TAS and $\mathrm{Cu}, \mathrm{Zn}$ or Se (Pearsons $r=0.945,0.964$ and 0.948 , respectively), and between $\mathrm{Cu} / \mathrm{Zn}, \mathrm{Cu} / \mathrm{Se}$ and $\mathrm{Zn} / \mathrm{Se}$ (Pearsons $r=0.995,0.999$ and 0.998, respectively).

\section{Discussion}

The TAS is a parameter accounting for the sum of the activities of all antioxidant molecules present in the material studied, most frequently in blood serum, and is able to reveal small differences much better than the measurement of single antioxidants [4]. TAS reflects the presence of antioxidant vitamins, enzymatic radical scavenger systems, unknown antioxidant compounds and various antioxidants interactions. TAS may be a marker of the antioxidant status of the body, and may reflect the level of supplementation with antioxidant vitamins and oxidative stress imposed on the organism [20].

The median antioxidant concentration of the women BM ranged from 0.497 (at 7 days of lactation) to $0.375 \mathrm{mmol} / \mathrm{L}$ (at week 16 of lactation), as can be seen in Table 1, which is in agreement with results previously reported [20]. This level was significantly lower than the median antioxidant 
content of the HM reported by other studies $(1.1 \mathrm{mmol} / \mathrm{L})$ [3]. However, this can be easily explained by invoking that these differences in antioxidant status of BM is influenced by maternal diet, time of year during which the milk samples were collected, ethnic group and the geographical area to which the mother belongs [3]. Comparison of means (paired samples $t$ test) showed significant differences between the results obtained at 7 days of breast-feeding and subsequent times. No differences were found throughout mature milk (see Fig. 1). In fact, lipophilic antioxidants (Coenzyme Q10, carotenoids, vitamin A and $\alpha$-tocopherol) show a tendency to decrease during early lactation times [19], and can contribute to the observed pattern. The need to attenuate the birth-related oxidative stress (rapid increase of alveolar $\mathrm{pO}_{2}$ and other physiologic processes involved in delivery) [2] explains the higher antioxidant requirements in the first weeks of lactation.

Copper and zinc are, besides iron, the two most extensively studied elements of BM. The results obtained in our study are in close agreement with literature data, displaying mean values in $\mathrm{HM}$ ranging from 0.16 to $5.7 \mathrm{mg} / \mathrm{L}$ for $\mathrm{Cu}$ and from 0.5 to $53 \mathrm{mg} / \mathrm{L}$ for $\mathrm{Zn}$ [28]. Results for Se and $\mathrm{Mn}$ are also agree with data reported in the literature, that range from 3 to $40 \mu \mathrm{g} / \mathrm{L}$ for $\mathrm{Mn}[45]$ and from 7.6 to $77.9 \mu \mathrm{g} / \mathrm{L}$ in the case of Se [37]. Our results are expressed in $\mu \mathrm{g} / \mathrm{kg}$, roughly, $\mu \mathrm{g} / \mathrm{L}$. The $\mathrm{Cu}, \mathrm{Zn}, \mathrm{Se}$ and $\mathrm{Mn}$ concentrations determined in the research entertained herein are similar to the values reported by other researchers [28, 37, 46-48].

As noted by other authors, the results obtained for metal concentrations are affected by strong standard deviations. In fact, large individual differences in the excretion of $\mathrm{Cu}$ and $\mathrm{Zn}$ through HM were also observed by Rodriguez and coworkers [28]. Whether these differences are or not related to the nutritional status of lactating mothers is still controversial [28].

The results obtained in our study show that the mean concentrations of all metals studied decrease throughout the lactation period under scrutiny, which can be related to nutritional requirements in early stages of life. Other researchers also described a decline for $\mathrm{Zn}, \mathrm{Cu}$, Se and $\mathrm{Mn}$ excretion through lactation period [28, 37, 38, 47]. It is well known that the initial level of metals decline gradually during the lactation period, due to the lower protein and fat contents in transitory and mature milk [36]. Most of the zinc and copper are bound to the protein fraction [22, 49], while $\mathrm{Mn}$ and $\mathrm{Se}$ are distributed between proteic and nonproteic fractions [33, 46]. The observed $\mathrm{Zn}, \mathrm{Cu}$ and $\mathrm{Mn}$ decrease with lactation time is probably due to the decreasing concentrations of proteins to which they are bound in BM [36].

Dorea [22, 49] described that the lactation time is the main factor that had influence upon $\mathrm{Zn}$ and $\mathrm{Cu}$ concentrations on HM. $\mathrm{Zn}$ is determinant for the baby growth rate, and its requirements are inversely proportional to newborns age [22]. As $\mathrm{Zn}$ requirements decrease as the infant grows, the decline in $\mathrm{Zn}$ concentrations in $\mathrm{HM}$ as lactation progresses does not inevitably result in a suboptimal $\mathrm{Zn}$ intake, but can represent a control mechanism by the mammary gland, which meets infant needs without imposing an unnecessary burden on maternal $\mathrm{Zn}$ status [50].

A significant correlation between TAS and metal concentrations was established for $\mathrm{Cu}, \mathrm{Zn}$ and $\mathrm{Se}$, which can corroborate the role of these elements in the antioxidant defense system. Mn does not appear to have such an important role in that system. Significant correlations were also observed between the metal concentrations throughout the entire lactation period under study, except for Mn, indicative that $\mathrm{Cu}, \mathrm{Zn}$ and $\mathrm{Se}$ can present a similar behavior in HM. Such correlations are insufficiently described in the literature until now, and further studies can enlighten the excretion mechanisms for these elements.

Additionally, the ratios between TAS and the oligoelements analyzed, as well as between the later, are not constant, suggesting that the decrease observed in the parameters is not a consequence of a simple dilution of the milk throughout the lactation. In fact, secretion of $\mathrm{Zn}$ and $\mathrm{Cu}$ seems not to be the result of simple diffusion, but of active transport through the mammary gland [51]. In a recent study, Kelleher and Lönnerdal [29] addressed the molecular processes through which the mammary gland regulates milk trace mineral transport. The utilization of rodent models to determine changes in mammary gland $\mathrm{Zn}$ and $\mathrm{Cu}$ transporter expression and localization that occur throughout lactation clearly demonstrated that the concentrations of these oligoelements are regulated temporally through coordinated changes in gene expression, protein levels and localization of mineral-specific transporters. No similar studies were found for Se, but the results described in the present paper can point for further investigations in this field.

Factors such as women age and number of previous childbirths have been widely described in the literature, as influencing $\mathrm{Zn}$ concentration in HM. Higher levels of $\mathrm{Zn}$ and $\mathrm{Cu}$ were found in younger mothers and in primipara [32]. Our results show a significant difference for $\mathrm{Cu}$ and $\mathrm{Zn}$ concentrations between primipara when compared to women with previous children, but only for samples collected at 7 days of breast-feeding. No differences were observed for later stages of lactation. In the case of Mn, we found continuous significant higher levels in primipara throughout the course of lactation. In the case of Se, no differences were found relative to the number of previous children.

With respect to the mothers age, no correlation was found whatsoever, either for trace metal concentrations or TAS. These results are consistent with the findings of 
Bocca and coworkers [46], that describe no marked agerelated differences for $\mathrm{Cu}, \mathrm{Zn}$ and $\mathrm{Mn}$ concentrations when the women studied were pooled into two age groups, namely under and over 30 years.

\section{Conclusion}

Significant correlations were found between TAS and $\mathrm{Cu}$, $\mathrm{Zn}$ and $\mathrm{Se}$ (not $\mathrm{Mn}$ ), suggesting some involvement of these trace metals in the antioxidant status of BM. The decreases of $\mathrm{Cu}, \mathrm{Zn}$ and Se were also correlated, but not proportional between them, suggesting diverse excretion mechanisms for all.

The findings presented in the present research effort clearly will have a potential impact in the design of baby foods, by allowing production of a tailor-made milk replacer according to the age of the (suckling) baby. Also, positive implications for the mothers without milk production can be foreseen, since their babies could have an adequate "milk" replacer with the same composition variations as real human milk.

\section{References}

1. Aycicek A, Erel O, Kocyigit A, Selek S, Demirkol MR (2006) Applied nutritional investigation: breast milk provides better antioxidant power than does formula. Nutrition 22:616-619

2. Quiles JL, Ochoa JJ, Ramirez-Tortosa MC, Linde J, Bompadre S, Battino M, Narbona E, Maldonado J, Mataix J (2006) Coenzyme Q concentration and total antioxidant capacity of human milk at different stages of lactation in mothers of preterm and full-term infants. Free Rad Res 40(2):199-206

3. VanderJagt DJ, Okolo SN, Costanza A, Blackwell W, Glew RH (2001) Antioxidant content of the milk of Nigerian women and the sera of their exclusively breast-fed infants. Nutr Res 21:121-128

4. Turoli D, Testolin G, Zanini R, Bellù R (2004) Determination of oxidative status in breast and formula milk. Acta Paediatr 93:1569-1574

5. Ezaki S, Ito T, Suzuki K, Tamura M (2008) Association between total antioxidant capacity in breast milk and postnatal age in days in premature infants. J Clin Biochem Nutr 42:133-137

6. Buescher ES (2001) Anti-inflammatory characteristics of human milk: how, where, why. Adv Exp Med Biol 501:207-222

7. Leung FY (1998) Trace elements that act as antioxidants in parenteral micronutrition. J Nutr Biochem 9:304-307

8. Friel JK, Friesen RW, Harding SV, Roberts LJ (2004) Evidence of oxidative stress in full-term healthy infants. Pediatr Res 56(6):878-882

9. Granot E, Golan D, Rivkin L, Kohen R (1999) Oxidative stress in healthy breast fed versus formula fed infants. Nutr Res 19(6):869879

10. Robles R, Palomino N, Robles A (2001) Oxidative stress in the neonate. Early Human Dev 65:S75-S81

11. Mezetti A, Lapenna D, Pierdomenico SD, Calafiore AM, Costantini F, Riario-Sforza G, Imbastaro T, Neri M, Cuccurullo F (1995) Vitamins E, C, and lipid peroxidation in plasma, and arterial tissue of smokers, and non-smokers. Atherosclerosis 112:91-99
12. Hercberg S, Galan P, Prezios P, Alfarez MJ, Vazquez C (1998) The potential role of antioxidant vitamins in preventing cardiovascular diseases and cancer. Nutrition 14:513-520

13. Knight JA (2000) Free radicals, antioxidants, and the immune system. Ann Clin Lab Sci 30:145-158

14. Lucey JF, Dangman B (1984) A re-examination of the role of oxygen in retrolental fibroplasia. Pediatrics 73:82-96

15. Varsila E, Pitkanen O, Hallman M, Andersson S (1994) Immaturity-dependent free radical activity in premature infants. Ped Res 36:55-59

16. Saugstad OD (1996) Mechanisms of tissue injury by oxygen radicals: implications for neonatal disease. Acta Paediatr 85:1-4

17. Bray TM, Levy MA (1998) The role of antioxidants in free radicalmediated diseases in premature infants. In: Huang YS, Sinclair AJ (eds) Lipids in infant nutrition. AOCS Press, Champaign, IL, pp 111-119

18. Lindemann JH (1989) The total free radical trapping ability of cord blood plasma in preterm and term babies. Pediatr Res 26:20-24

19. Niklowitz P, Menke T, Giffei J, Andler W (2005) Coenzyme Q10 in maternal plasma and milk throughout early lactation. Biofactors 25:67-72

20. Ziobro A, Bartosz G (2003) A comparison of the total antioxidant capacity of some human body fluids. Cell Mol Biol Lett 8:415-419

21. Miller NJ, Rice-Evans C, Davies MJ, Gopinathan V, Milner A (1993) A novel method for measuring antioxidant capacity, and its application to monitoring the antioxidant status in neonates. Clin Sci 84:407-412

22. Dorea JG (2000) Zinc in human milk. Nutr Res 20(11):1645-1687

23. Arnaud J, Favier A (1995) Copper, iron, manganese and zinc contents in human colostrum and transitory milk of French women. Sci Total Environ 159:9-15

24. Roekens E, Deelstra H, Robberecht H (1985) Trace elements in human milk: selenium, a case study. Sci Total Environ 42:91-108

25. Karra MV, Kirksey A, Galal O, Bassily NS, Harrison GG, Jerome NW (1988) Zinc, calcium, and magnesium concentrations in milk from American and Egyptian women throughout the first 6 months of lactation. Am J Clin Nutr 47:642-648

26. Ohtake M, Tamura T (1993) Changes in zinc and copper concentrations in breast milk and blood of Japanese women during lactation. J Nutr Sci Vitaminol 39:189-200

27. Casey CE, Neville MC, Hambidge KM (1989) Studies in human lactation: secretion of zinc, copper, and manganese in human milk. Am J Clin Nutr 49:773-785

28. Rodríguez EMR, Alaejos MS, Romero CD (2000) Concentrations of iron, copper and zinc in human milk and powdered infant formula. Int J Food Sci Nutr 51:373-380

29. Kelleher SL, Lönnerdal B (2005) Molecular regulation of milk trace mineral homeostasis. Mol Aspect Med 26:328-339

30. Langley SC, Kelly FJ (1992) Effect of food restriction on hyperoxia-induced lung injury in preterm guinea pig. Am J Physiol Lung Cell Mol Physiol 263:L357-L362

31. Kotecha S (2000) Lung growth: implications for the newborn infant. Arch Dis Child Fetal Neonatal Ed 82(1):69F-74F

32. Frkovic A, Medugorac B, Alebic-Juretic A (1996) Zinc levels in human milk and umbilical cord blood. Sci Total Environ 192:207212

33. Michalke B (2006) Trace element speciation in human milk. Pure Appl Chem 78(1):79-90

34. Lonnerdal B, Stanislowski AG, Hurley LS (1980) Isolation of a low molecular weight zinc binding ligand from human milk. J Inorg Biochem 12:71-78

35. Lonnerdal B, Hoffman B, Hurley LS (1982) Zinc and copper binding proteins in human milk. Am J Clin Nutr 36:1170-1176

36. Abdulrazzaq YM, Osman N, Nagelkerke N, Kosanovic M, Adem A (2008) Trace element composition of plasma and breast milk of well-nourished women. J Environ Sci Health Part A 43:329-334 
37. Torres MA, Verdoy J, Alegría A, Barberá R, Farré R, Lagarda MJ (1999) Selenium contents of human milk and infant formulas in Spain. Sci Total Environ 228:185-192

38. Yamawaki N, Yamada M, Kan-no T, Kojima T, Kaneko T, Yonekubo A (2005) Macronutrient, mineral and trace element composition of breast milk from Japanese women. J Trace Elem Med Biol 19:171-181

39. Litov RE, Combs GF (1991) Selenium in pediatric nutrition. Pediatrics 87(3):339-351

40. Michalke B, Caroli S (2004) Speciation of trace elements. In: Selinus O, Alloway B, Centeno JA, Finkelman RB, Fuge R, Lindh U, Smedley P (ed) Essentials of medical geology_impacts of the natural environment on public health. Academic Press, New York. ISBN:0126363412, pp 609-632

41. Arnaud J, Andre D, Bouillet MC, Kia D, Favier A (1992) Problems associated with the use of exclusion-diffusion chromatography for identification of zinc ligands in human milk. J Trace Elem Electrolytes Health Dis 6(2):81-90

42. Lombeck I, Kasperek K, Harbisch HD, Feinendegen LE, Bremer HJ (1977) The selenium state of healthy children. I. Serum selenium concentration at different ages; activity of glutathione peroxidase of erythrocytes at different ages; selenium content of food of infants. Eur J Pediatr 125(1):81-88

43. Arthur JR, Nicol F, Beckett GJ (1992) The role of selenium in thyroid hormone metabolism and effects of selenium deficiency on thyroid hormone and iodine metabolism. Biol Trace Elem Res $33: 37-42$
44. Edmond KM, Zandoh C, Quigley MA, Amenga-Etego S, OwusuAgyei S, Kirkwood BR (2006) Delayed breastfeeding initiation increases risk of neonatal mortality. Pediatrics 117:380-386

45. Caroli S, Alimonti A, Coni E, Petrucci F, Senofonte O, Violante N (1994) The assessment of reference values for elements in human biological tissues and fluids-a systematic review. Crit Rev Anal Chem 24(5-6):363-398

46. Bocca B, Alimonti A, Coni E, Di Pasquale M, Giglio L, Bocca AP, Caroli S (2000) Determination of the total content and binding pattern of elements in human milk by high performance liquid chromatography-inductively coupled plasma atomic emission spectrometry. Talanta 53:295-303

47. Leotsinidis M, Alexopoulos A, Kostopoulou-Farri E (2005) Toxic and essential trace elements in human milk from Greek lactating women: association with dietary habits and other factors. Chemosphere 61:238-247

48. Kosanovic M, Adem A, Jokanovic M, Abdulrazzaq YM (2008) Simultaneous determination of cadmium, mercury, lead, arsenic, copper, and zinc in human breast milk by ICP-MS/Microwave digestion. Anal Lett 41:406-416

49. Dorea JG (2000) Iron and copper in human milk. Nutrition $16: 209-220$

50. Krebs NF, Hambidge KM (1986) Zinc requirements and zinc intakes of breast-fed infants. Am J Clin Nutr 43:288-292

51. Domellöf M, Lönnerdal B, Dewey KG, Cohen RJ, Hernell O (2004) Iron, zinc, and copper concentrations in breast milk are independent of maternal mineral status. Am J Clin Nutr 79:111-115 